\title{
有限要素法による織物強化熱可塑性樹脂のプレス成形解析
}

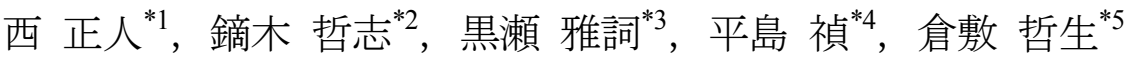

\section{Forming simulation of thermoplastic pre-impregnated textile reinforcement by finite element method}

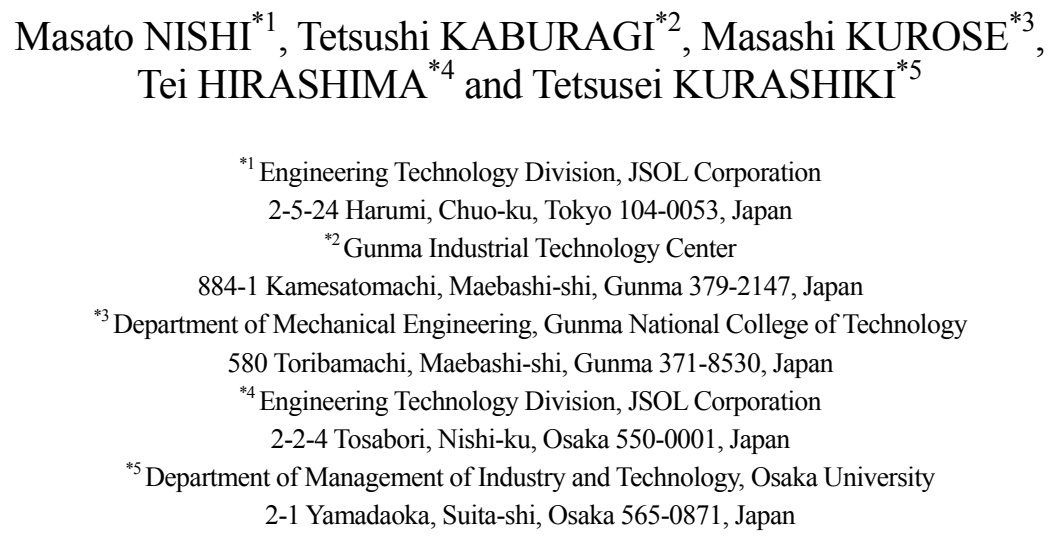

\section{Received 20 August 2014}

\begin{abstract}
In this paper, we propose a new FE model of a carbon fiber reinforced thermoplastic (CFRTP) in order to capture the deformation during a thermoforming process because the thermoforming process of CFRTP has increased its presence in the automotive industry for its wide applicability to the mass production car. The proposed model can describe temperature dependent non-linear bending property of CFRTP by a set of elements which consists of two shell elements with membrane elements in between them. The membrane elements represent temperature dependent anisotropic in-plane behavior by calculating stress contributions of the textile reinforcement and thermoplastic in a parallel system. By applying Reuss model to the stress calculation of thermoplastic, the in-plane shear behavior which is the key deformation mode during forming can be accurately predicted. FE model is constructed based on the results of three point bending and bias-extension experiments which are conducted in the range of the process temperature. Thermoforming simulations are presented and compared to experimental results. Simulated outline and shear angle are in good agreement with experimental results. It will be shown by sensitivity study that the effect of the temperature plays an important role in deformation during a non-isothermal forming process.
\end{abstract}

Key words : Carbon fiber reinforced thermoplastic (CFRTP), Finite element method (FEM), In-plane shear, Out-of-plane bending, Textile reinforcement, Thermoforming

\section{1. 緒言}

炭素繊維強化樹脂材料（Carbon Fiber Reinforced Plastic, CFRP）は比強度および比剛性に優れることから，航空 機分野ではその適用拡大により大幅な機体の軽量化が実現されている．排出ガス規制が強化され，車両の軽量化 による燃費向上が求められる自動車分野においても金属に代わる材料として，その適用拡大が期待されている.

No. 14-00424 [DOI: 10.1299/transjsme.2014smm0354]

*1 正員，(株) JSOL エンジニアリングビジネス事業部（邓104-0053＼cjkstart東京都中央区晴海 2-5-24）

*2 正員，群馬産業技術センター（广379-2147 群馬県前橋市亀里町 884-1）

*3 正員, 群馬工業高等専門学校 機械工学科（干371-8530 群馬県前橋市鳥羽町 580)

${ }^{* 4}$ 正員, (株) JSOL エンジニアリングビジネス事業部（†550-0001 大阪府大阪市西区土佐堀 2-2-4）

*5 正員, 大阪大学大学院 工学研究科（广565-0871 大阪府吹田市山田丘 2-1）

E-mail of corresponding author: nishi.masato@jsol.co.jp 
自動車分野では量産成形技術の課題から CFRP の適用範囲は一部の高級車にとどまっていたが, 近年では 10 分以 内で成形可能な RTM（Resin Transfer Molding）工法も開発され，成形時間が大幅に短縮されている．それでも量 産車に要求される成形サイクルは 1 分以内であり，量産車へ本格的に適用されるためには，更なる成形時間の短 縮が必要になる，そこで，より成形時間を短縮できる工法として，熱可塑性樹脂を含浸させた炭素繊維（Carbon Fiber Reinforced ThermoPlastic, CFRTP) シートを加熱してプレス成形する工法が注目されている. CFRTP シート のプレス成形では，プレス成形の前工程においてプリプレグを所定の方向に積層し，熱間プレスにて樹脂を含浸 させ積層 CFRTP シートを作成する，この工程では温度，成形圧，加圧時間等の成形条件により CFRTP シートの 繊維体積含有率（Volume fraction, $\mathrm{V}_{\mathrm{f}}$ ) が変化し，材料特性が大きく変化することが知られている．熱間プレスに て CFRTP シートを作成した後，成形温度まで加熱したCFRTP シートを金型にてプレス成形し，冷却した後に製 品を取り出す．CFRTP のプレス成形工法は金型の温度条件から大きく 2 種類に分類できる．一つは，金型に加熱 冷却装置を埋め込み金型を成形温度まで加熱した状態でプレス成形し，その後，冷却する工法である．もう一つ は，常温の金型を用いてプレス成形工程と冷却工程を明確に区別せず，成形しながら泠却する工法である，後者 の工法では，成形と冷却の工程を同時に行い，金型の加熱冷却が必要ないため 1 分以内での成形が可能になる (Long, 2007). CFRTP シートの常温金型を用いたプレス成形は, 大量生産に適した非常に魅力的な工法であるが, 制御パラメータが多くその挙動解析のためのシミュレーション手法の確立が求められている.

繊維強化材のプレス成形に対するシミュレーションアプローチとしては, RTM 工法の賦形工程を対象とし, 樹 脂を含浸させる前のドライな織物䋊維基材のプレス成形シミュレーションの有限要素モデルが過去に多く提案さ れている(Sharma and Sutcliffe, 2004, Skordos, et al., 2007, Aimene, et al., 2011). しかし，そのほとんどはプレス時の 局所的な変形を予測するために重要な面外の曲げ剛性を考慮していない. 著者ら(西他，2014a，西他，2014b)は曲 げ剛性を考慮し，さらに面内のせん断特性の引張依存性まで表現可能なモデルを提案している，一方で，熱可塑 性樹脂を含浸させた CFRTP シートのプレス成形では材料を加熱しプレス成形するため, 成形時の温度が成形挙 動に与える影響が大きく材料特性の温度依存性の考慮が重要である.また, CFRTP シートは高温時に曲げ特性が 非線形性を示すことも実験で観測されている(Margossian, et al., 2014). Wang ら(Wang, et al., 2013)や Haanappel ら (Haanappel, et al., 2014)は，曲げ岡性を考慮する CFRTP シートのモデルを提案している．しかし，線形の曲げ特性 のみを考え, 高温時の曲げ特性の非線形性までは考慮していない. また, 面内特性は異方性超弾性モデルに粘性 を加えることで表現している，そのため，プリプレグから熱間プレスにて CFRTP シートを作成する際の成形条 件の変更により $\mathrm{V}_{\mathrm{f}}$ が変化し，その材料特性が変化した際には，再び材料実験を行い，材料物性值を調整する必要 がある．さらに Wang らおよび Haanappel らのモデルはいずれも金型を加熱し，CFRTP シートを一定温度にてプ レス成形する工法を対象としており，金型との接触による CFRTP シートの温度変化が成形挙動に与える影響に ついては検証されていない.

本研究では，成形時間 1 分以内が実現可能な工法として注目される常温の金型を用いるプレス成形工法を対象 とし, CFTRP シートの高温時の曲げ特性の非線形性を考慮したモデルを提案する. 面内特性については, 繊維基 材と樹脂の応力成分を計算し, 熱可塑性樹脂の影響による温度依存性を考慮した非線形性かつ異方性を有する特 性を表現する.さらに，面内せん断挙動を正確に表現するため，節点の変位から樹脂のひずみ成分を計算する際 に, Reuss モデル(Hull and Clyne, 1996)を導入し，樹脂の素材の材料特性と $\mathrm{V}_{\mathrm{f}}$ から CFRTP シートのせん断特性を 予測できるモデルを提案する，提案モデルを用いて，成形中の温度変化とそれに伴う材料特性の変化を考慮した 熱構造連成解析を行い，金型との接触による CFRTP シートの温度変化が成形挙動に与える影響を検証する.ま た, 実験結果と比較することで提案モデルにおけるプレス成形時の変形挙動を評価し, 良好な結果を得たので報 告する.

\section{2. 織物 CFRTP シートの FE モデル提案}

本研究で提案する CFRTP シートモデルでは, 面内特性は膜要素, 面外曲げ特性は膜要素に付加したシェル要 素で表現する．本章では，面外曲げ特性を表現するモデル化手法および面内特性を表現する面内モデル化手法に ついて，それぞれの詳細を述べる。 


\section{$2 \cdot 1$ 面外挙動の FE モデル提案}

織物シートは複雑な 3 次元構造を持つ不連続な材料であり，その曲げ特性は圧縮・引張の面内特性からは算定 できない，そのため，面内の引張とせん断のみの表現に注目し，面外の曲げ岡性は面内の引張剛性に対し非常に 小さいとして，曲げ岡性を持たない膜要素を用いた解析モデルが良く用いられる(Sharma and Sutcliffe, 2004, Skordos, et al., 2007, Aimene, et al., 2011). しかし, プレス成形のように局所変形が重要である現象を解析するには, 曲げ岡性の考慮が必要不可欠である。

著者ら(西他，2014b)は，図 1 に示すように厚み中心位置に置いた面内特性を表現する膜要素に，面外曲げ岡性 を考慮するため膜要素と節点を共有するシェル要素を 2 要素付加するモデルを提案している.

さらに, CFRTP シートのプレス成形を解析対象とする場合には，高温時に曲げ特性が大きな非線形性を持つた めに，本研究では，前報で提案した曲げ岡性を付加するシェルモデルを，非線形性を有する曲げ特性を表現でき るように拡張する.

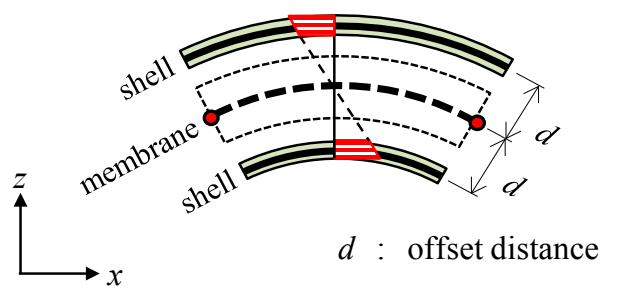

(a) Shell and membrane combined model
Experimental measurement

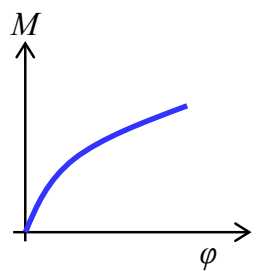

Defined curve on shell elements

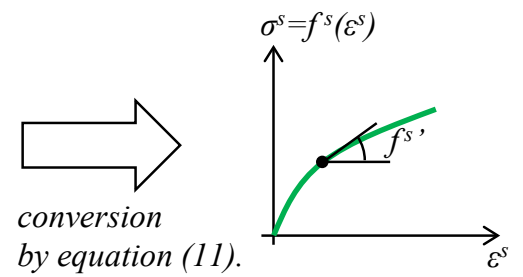

(b) Non-linear bending property of CFRTP

Fig. 1 Schematics of out-of-plane model considering non-linear bending property of CFRTP sheet. The shell reference surface is offset to enhance the effect of bending stiffness. This enables the shell elements to have a stiffness small enough not to affect the in-plane properties. Non-linear stress strain relationship can be defined on shell elements.

シェル要素の法線方向を $z$ とし，厚み中心位置（中立面）を $z=0$ とする. 本提案モデルでは節点の回転変位か らシェル要素のひずみを計算する際に，2つのシェル要素が膜要素の節点位置から等距離反対側に配置している ものとして計算する．平面応力を仮定したシェル要素において，節点の回転変位増分 $\Delta \theta$ にり生じるひずタ増 分 $\boldsymbol{\Delta} \boldsymbol{\varepsilon}^{\mathrm{s}}$ は，式（1）で記述できる．また，シェル要素の中立面からの距離を $d$ とし，シェル要素に与える板厚はそ れぞれ $t / 2$ とすると, $z$ は式 $(2)$ の範囲を取るため, 回転変位に対するシェル要素のひずみは $d$ の值に応じて大 きく計算される. なお，添え字の $s$ は膜要素に付加したシェル要素を示す.

$$
\begin{gathered}
\Delta \boldsymbol{\varepsilon}^{s}=\left\{\begin{array}{l}
\Delta \varepsilon_{x}^{s} \\
\Delta \varepsilon_{y}^{s} \\
\Delta \varepsilon_{x y}^{s}
\end{array}\right\}=z\left\{\begin{array}{cc}
\frac{\partial}{\partial x} & 0 \\
0 & \frac{\partial}{\partial y} \\
\frac{\partial}{2 \partial y} & \frac{\partial}{2 \partial x}
\end{array}\right\}\left\{\begin{array}{l}
\Delta \theta_{y} \\
\Delta \theta_{x}
\end{array}\right\} \\
-d-\frac{t}{4} \leq z \leq-d+\frac{t}{4}, \quad d-\frac{t}{4} \leq z \leq d+\frac{t}{4}
\end{gathered}
$$

ここで， $\Delta \theta_{y}, \Delta \theta_{x}$ はそれぞれ $y$ 軸周り， $x$ 軸周りの回転角増分である.

微小な変形増分を仮定すると, 本モデルのシェル要素の曲げモーメント増分 $\Delta \mathbf{M}$ は, 下記にて表すことができ る.

$$
\mathbf{\Delta M}=\left\{\Delta M_{y} \quad \Delta M_{x} \quad \Delta M_{x y}\right\}^{T}
$$




$$
\begin{aligned}
& \Delta M_{y}=\int_{-d-t / 4}^{-d+t / 4} \Delta \sigma_{x}^{s} z d z+\int_{d-t / 4}^{d+t / 4} \Delta \sigma_{x}^{s} z d z, \quad \Delta M_{x}=\int_{-d-t / 4}^{-d+t / 4} \Delta \sigma_{y}^{s} z d z+\int_{d-t / 4}^{d+t / 4} \Delta \sigma_{y}^{s} z d z \\
& \Delta M_{x y}=\int_{-d-t / 4}^{-d+t / 4} \Delta \sigma_{x y}^{s} z d z+\int_{d-t / 4}^{d+t / 4} \Delta \sigma_{x y}^{s} z d z
\end{aligned}
$$

ここで， $\Delta M_{y}, \Delta M_{x}$ はそれぞれ $y$ 軸周り， $x$ 軸周りのモーメント増分， $\Delta M_{x y}$ はねじりモーメント増分である. $\Delta \sigma^{s}$ はシェル要素の応力増分を示す. シェル要素に与える応力ひずみ特性の勾配を $f^{s^{\prime}}$ とすると式 (4) および (5) は次のように変換される.

$$
\begin{aligned}
& \Delta M_{y}=\int_{-d-t / 4}^{-d+t / 4} f_{x}^{s^{\prime}} \Delta \varepsilon_{x}^{s} z d z+\int_{d-t / 4}^{d+t / 4} f_{x}^{s^{\prime}} \Delta \varepsilon_{x}^{s} z d z, \quad \Delta M_{x}=\int_{-d-t / 4}^{-d+t / 4} f_{y}^{s^{\prime}} \Delta \varepsilon_{y}^{s} z d z+\int_{d-t / 4}^{d+t / 4} f_{y}^{s^{\prime}} \Delta \varepsilon_{y}^{s} z d z \\
& \Delta M_{x y}=\int_{-d-t / 4}^{-d+t / 4} f_{x y}^{s^{\prime}} \Delta \varepsilon_{x y}^{s} z d z+\int_{d-t / 4}^{d+t / 4} f_{x y}^{s^{\prime}} \Delta \varepsilon_{x y}^{s} z d z
\end{aligned}
$$

節点回転からのひずみを算出する際に加えて, ここでも参照面の移動距離 $d$ に比例して節点のモーメント力は大 きく計算される．そのため，面内挙動に与える影響が無視できるほど小さな剛性しかシェル要素に与えることな く，大きな曲げ抵抗を表現できる.さらに，式（6）および（7）は，式（1）を用いて次のように変換される.

$$
\begin{aligned}
& \Delta M_{y}=f_{x}^{s^{\prime}} \Delta\left(\frac{\partial \theta_{y}}{\partial x}\right) t\left(d^{2}+\frac{t^{2}}{48}\right), \Delta M_{x}=f_{y}^{s^{\prime}} \Delta\left(\frac{\partial \theta_{x}}{\partial y}\right) t\left(d^{2}+\frac{t^{2}}{48}\right) \\
& \Delta M_{x y}=\frac{1}{2} f_{x y}^{s^{\prime}} \Delta\left(\frac{\partial \theta_{y}}{\partial y}+\frac{\partial \theta_{x}}{\partial x}\right) t\left(d^{2}+\frac{t^{2}}{48}\right)
\end{aligned}
$$

$y$ 軸周りの曲率 $\phi_{y}, \quad x$ 軸周り曲率 $\phi_{x}$, およびねじり率 $\phi_{x y}$ の増分 $\Delta \varphi$ は，式（10）にて表されるため，これを式

(8)，（9）に代入すれば，シェル要素に与える $x$ 方向および $y$ 方向の応力ひずみ特性の勾配 $f_{x}^{s^{\prime}}, f_{y}^{s^{\prime}}$ およびせん 断の応力ひずみ特性の勾配 $f_{x y}{ }^{\prime}$ は, $t, d$, 曲げ実験で観測されるモーメント曲率曲線，およびねじり実験で観測 されるねじりモーメント-ねじり率曲線の傾き（ $\Delta M / \Delta \phi ）$ により式（11）にて表すことができる.

$$
\begin{aligned}
& \Delta \boldsymbol{\varphi}=\left\{\begin{array}{l}
\Delta \phi_{y} \\
\Delta \phi_{x} \\
\Delta \phi_{x y}
\end{array}\right\}=\left\{\begin{array}{ll}
\frac{\partial}{\partial x} & 0 \\
0 & \frac{\partial}{\partial y} \\
\frac{\partial}{\partial y} & \frac{\partial}{\partial x}
\end{array}\right\}\left\{\begin{array}{l}
\Delta \theta_{y} \\
\Delta \theta_{x}
\end{array}\right\} \\
& f_{x}^{s^{\prime}}=\frac{\Delta M_{y}}{\Delta \phi_{y}} \frac{48}{t\left(48 d^{2}+t^{2}\right)}, \quad f_{y}^{s^{\prime}}=\frac{\Delta M_{x}}{\Delta \phi_{x}} \frac{48}{t\left(48 d^{2}+t^{2}\right)}, \quad f_{x y}^{s^{\prime}}=2 \frac{\Delta M_{x y}}{\Delta \phi_{x y}} \frac{48}{t\left(48 d^{2}+t^{2}\right)}
\end{aligned}
$$

図 1(b)に示すように曲げ試験やねじり試験で得られる非線形性を有する曲げ特性も, 式 (11) を用いることで, 表現することができる，なお，面外特性を非線形性まで考慮したモデルに拡張しても，本モデルでは，面外の曲 げ特性と面内の特性は相互依存がなく完全に独立なものとして扱える.

\section{2 - 2 面内挙動の FE モデル提案}

CFRTP シートの面内挙動は，異方性かつ非線形特性を考慮する織物繊維基材モデルと温度依存性を有する等方 性弾塑性体の熱可塑性樹脂モデルにより表現する．繊維基材モデルと熱可塑性樹脂モデルは並列構成とし，それ ぞれに膜要素を用いる. また, 織物 CFRTP シートは緎維方向の引張りに対する変形抵抗は大きいが, 面内のせ 
ん断に対しては樹脂変形が主であり抵抗は非常に小さく, プレス成形におけるせん断変形の影響が大きい(Boisse, et al., 2006). そのため，特にせん断特性を正確に表現することを重視したモデル化手法を提案する.

簡単のため, 繊維基材成分の応力計算には, Ivanov ら(Ivanov and Tabiei, 2004)が提案するマイクロメカニカルモ デルを適用する．図２に示す代表体積要素（Representative Volume Cell, RVC）を仮定し，繊維束は直交異方性弾 性体とする. 繊維束の物性值のほか, 䋊維束の幅 $w$, 厚み $t$, 断面積 $S$, 繊維束の間隔 $s$ および縦糸と横糸の交差 角度 $\theta^{w e}, \theta^{w a}$ などの織構造情報やせん断ロッキング角度を定義し, RVC の平均ひずみ, 平均応力は次に示す手 順にて計算する。
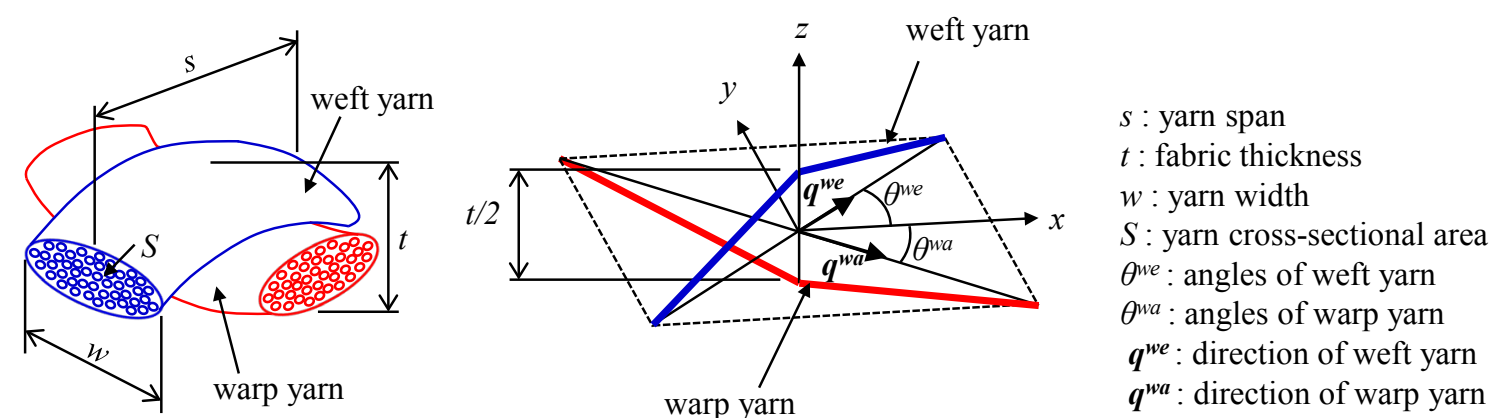

Fig. 2 Representative volume cell (RVC) of micromechanical model (Ivanov and Tabiei, 2004). This micromechanical model is adapted to the membrane element within our proposed shell and membrane combined model in order to describe the in-plane behavior of textile reinforcement. This textile reinforcement model can account for the trellising with reorientation of the yarns and their locking.

変形勾配テンソルから緎維束の面内回転を計算

式（12）に示すように䋊維束の面内方向ベクトル $\mathbf{q}^{\text {we }}, \mathbf{q}^{\text {wa }}$ を定め, 変形勾配テンソルを用いて逐次 アップデートする. なお, 添え字の we と wa はそれぞれ横糸（weft yarn）, 縦糸（warp yarn）を示す.

$$
\mathbf{q}^{w e}=\left\{\cos \theta^{w e} \sin \theta^{w e}\right\}^{T}, \quad \mathbf{q}^{w a}=\left\{\cos \theta^{w a} \quad \sin \theta^{w a}\right\}^{T}
$$

（2）平均ひずみを要素座標から繊維束座標に変換

$\mathrm{RVC}$ の平均ひず夕増分は, 座標変換マトリックスにより $z$ 軸周りに $\theta^{w e}, \theta^{w a}$ 回転され, 繊維束の材 料座標におけるひずみ増分に変換される。

(3) 繊維束ひずみから繊維束応力を計算

繊維束の材料座標におけるひずみ増分から，繊維束の各応力増分が計算される.なお，繊維束には 直交異方性モデルを用いる.

$$
\begin{aligned}
& \Delta \sigma_{11}^{w e}=\frac{2 E_{11}^{y} \Delta \varepsilon_{11}^{w e} S}{s t_{e}}, \quad \Delta \sigma_{11}^{w a}=\frac{2 E_{11}^{y} \Delta \varepsilon_{11}^{w a} S}{s t_{e}} \\
& \Delta \sigma_{22}^{w e}=\alpha E_{22}^{y} \Delta \varepsilon_{22}^{w e}, \quad \Delta \sigma_{22}^{w a}=E_{22}^{y} \Delta \varepsilon_{22}^{w a} \\
& \Delta \sigma_{12}^{w e}=\alpha G_{12}^{y} \Delta \varepsilon_{12}^{w e}, \quad \Delta \sigma_{12}^{w a}=\alpha G_{12}^{y} \Delta \varepsilon_{22}^{w a}
\end{aligned}
$$

ここで, $\Delta \sigma_{11}^{w e}, \Delta \sigma_{22}^{w e}, \Delta \sigma_{12}^{w e}$ および $\Delta \sigma^{w a}{ }_{11}, \Delta \sigma^{w a}{ }_{22}, \Delta \sigma^{w a}{ }_{12}$ はそれぞれ縦糸，横糸の繊維束 の繊維方向, 繊維直交方向の直応力とせん断応力の増分, $E^{y}{ }_{11}, E^{y}{ }_{22}, G^{y}{ }_{12}$ は繊維束の繊維方向ヤング 率，繊維直交方向のヤング率，せん断弾性率である。 なお，添え字の $y$ は繊維束（yarn）を示す． $t_{e}$ は 有効厚さ（織物繊維基材の面密度を繊維束質量密度で除して得る值）である. 繊維基材は，面内せん 断変形に対し, せん断ロッキングに至るまでは繊維束が相対的なずれにより面内に回転するため, 繊 維束の横方向の変形が生じない. そのため，本マイクロメカニカルモデルにおいて，せん断ロッキン グ $\theta_{\text {lock }}$ に至るまで繊維束の繊維直交方向の圧縮変形やせん断変形はないと仮定し，スケールファクタ 
一 $\alpha$ により，繊維束の回転ずれによる効果を考慮する．せん断ロッキング以前は絨維束同士の横方向 の接触が生じず，䋊維束横方向の圧縮変形もないと仮定し， $\alpha$ は 0 の值をとり，ロッキング以降は 1

の值をとる.

(4) 繊維束応力を要素座標の平均応力に変換

式（13）〜（15）で計算された繊維束の応力増分は，再び座標変換マトリックスにより $z$ 軸周りに $\theta^{w e}, \theta^{w a}$ 回転 RVC 座標における応力増分に変換される. 本マイクロメカニカルの RVC 座標における 平均応力は最終的に，2つの繊維束の応力の平均值として求められる.

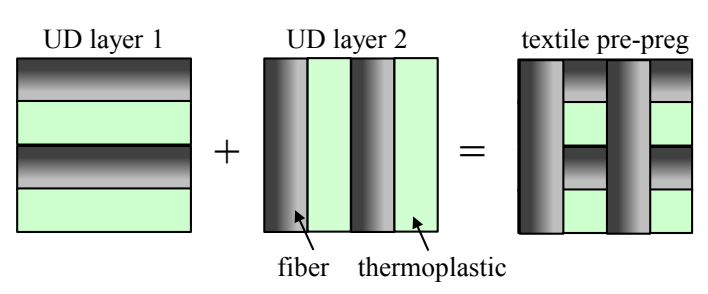

(a) Before deformation

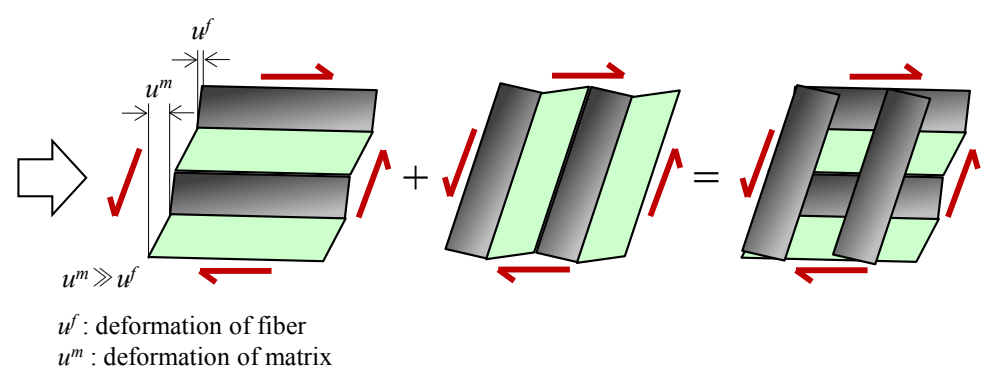

(b) After shear deformation

Fig. 3 Schematic illustration of textile as superposed two UD layers. To simplify the meso-scale material structure, the textile pre-preg is made up of two different superposed layers which consist of unidirectional fibers (UD layer). The fiber direction of first layer is oriented initially at $90^{\circ}$ with respect to the second layer. Each layer is deformed freely without any interaction.

次に樹脂成分の応力計算方法について記述する．樹脂モデルは繊維基材モデルの膜要素と節点を共有する膜要 素にて表現する。ここでは von-Mises 降伏型の弾塑性モデルを用い, 温度依存性を有する応力ひず夕特性を考慮 する. 面内特性の表現には繊維基材の応力成分と樹脂の応力成分を別々に計算する並列モデルとする. 繊維束方 向にあたる $0 / 90$ 方向は樹脂の応力成分に対して繊維基材の応力成分が著しく大きいため, 樹脂の応力成分がマク ロ特性へ与える影響は非常に小さい. 一方，せん断変形に対しては，前述のように繊維基材モデルにはせん断ロ ッキングに至るまでは応力が生じず，樹脂成分の応力のみが作用する.

織物 CFRTP シートのメゾスケールの材料構造を簡易化するため, 図 3(a)に示すように 2 つ異なる一方向繊維 強化層（UD 層）がそれぞれ $90^{\circ}$ 回転して配置されていると考える.2つの層に相互依存はなくそれぞれ独立に変 形すると仮定し，織構造の影響を無視する. 図3(b)に示すように，せん断変形下では，繊維と樹脂に同じせん断 応力が作用すると仮定するのが妥当であると考えられるため Reuss モデルを適用すれば, 樹脂ひずみ $\varepsilon^{m}{ }_{i j}$ は繊維ひ ずみ $\varepsilon_{i j}^{f}$ とプリプレグのマクロひずみ（つまり，膜要素のひずみ） $\varepsilon_{i j}$ と次の関係式で表せる. なお，添え字の $f$ $m$ はそれぞれ繊維（fiber）と樹脂（matrix）を示す.

$$
\varepsilon_{i j}^{m}=\frac{\varepsilon_{i j}-V_{f} \varepsilon_{i j}^{f}}{\left(1-V_{f}\right)}
$$

ここで， $V_{f}$ は繊維体積含有率である. 繊維の剛性は樹脂に比べて非常に大きく $\left.\varepsilon_{i j}^{m}{ }_{i j}{ }_{\varepsilon}^{f}{ }_{i j}, \varepsilon_{i j}\right\rangle_{\varepsilon}{ }_{i j}^{f}$ と考えれば $\varepsilon_{i j}^{m}$ は次式で近似できる.

$$
\varepsilon_{i j}^{m}=\frac{\varepsilon_{i j}}{\left(1-V_{f}\right)}
$$

繊維基材モデルと熱可塑性樹脂モデルはそれぞれに膜要素を用いて節点共有にて並列構成としているため，本 来は樹脂のひずみは膜要素のひずみと一致するが，樹脂のひずみの算出には式（17）を用いる. 算出された樹脂 の各ひずみ成分より弾塑性モデルにより樹脂の応力成分を計算し，繊維基材の応力成分に加算することで，プリ プレグの応力が求められる. 本モデルを用いることで, プレス成形で特に重要な面内せん断特性を樹脂の特性と $\mathrm{V}_{\mathrm{f}}$ から予測可能であり，プレス成形の前工程で CFRTP シートを作成する際に $\mathrm{V}_{\mathrm{f}}$ が変化した場合も，再度，実験 によりせん断特性を計測し材料物性值を調整することなく，そのせん断特性を予測できる. 


\section{3. 織物 CFRTP シートの材料モデル構築}

本研究では，母材に熱可塑性のアクリル樹脂（PMMA）を，強化基材に炭素繊維 3K 平織を用いた CFRTP シー

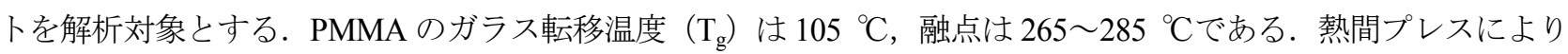
樹脂を含浸した 4 枚のプリプレグから積層 CFRTP シートを作成した. CFRTP シートの厚みは平均で $0.84 \mathrm{~mm}$, $\mathrm{V}_{\mathrm{f}}$ は平均で 70 \%であった．本章では，熱間プレス後の CFRTP シートのモデル構築について述べる．解析には汎 用有限要素解析コード LS-DYNA を用いる(Hallquist, 2006).

\section{$3 \cdot 1$ 面外挙動の材料モデル構築}

CFRTP シートの面外曲げ特性の温度依存性を把握寸るため, $\mathrm{T}_{\mathrm{g}}$ 以下の温度条件, $50{ }^{\circ} \mathrm{C}, 75{ }^{\circ} \mathrm{C}, 100{ }^{\circ} \mathrm{C}$ て 3 点曲げ試験を行い, CFRTP シートの曲げ特性を計測した。試験片は長さ $60 \mathrm{~mm}$, 幅 $25 \mathrm{~mm}$ の短冊型，支点間距離 は $30 \mathrm{~mm}$ とした.

シェルモデルには温度依存性を考慮した弾塑性モデルを用い，実験で得られた曲げ特性より式（11）によりシ エルモデルに与える条件を求める．シェルモデルの条件を表 1 に示す．提案モデルの各温度に対する面外曲げ挙 動の表現性を検証するため, 3 点曲げ試験と同等の試験片寸法, 境界条件を与える解析を行い, 解析結果を実験 結果と比較する．試験片は $1 \mathrm{~mm}$ サイズで要素分割し，要素数は 3000 要素である.

3 点曲げ試験から得られる曲げ応力ひずみ特性の実験結果と解析結果を図 4 に示寸. 最大荷重に至るまでの領 域で両者はよく合致しており，本提案モデルにて実験の曲げ特性をよく表現できていることがわかる.

Table 1 Defined parameters in shell element.

\begin{tabular}{|c|c|c|c|c|c|}
\hline \multicolumn{3}{|c|}{ Material parameters } & $50^{\circ} \mathrm{C}$ & $75^{\circ} \mathrm{C}$ & $100^{\circ} \mathrm{C}$ \\
\hline Young's modulus & $E^{s}$ & $\mathrm{MPa}$ & 100.12 & 97.76 & 70.52 \\
\hline Yield stress at $\varepsilon^{s}{ }_{y}=0 \%$ & $\sigma_{y}^{s}$ & $\mathrm{MPa}$ & 15.14 & 8.73 & 2.69 \\
\hline Yield stress at $\varepsilon^{s}=0.2 \%$ & $\sigma_{y}^{s}$ & $\mathrm{MPa}$ & 16.26 & 9.40 & 3.08 \\
\hline Yield stress at $\varepsilon^{s}{ }_{y}=0.5 \%$ & $\sigma_{y}^{s}$ & $\mathrm{MPa}$ & 16.56 & 10.26 & 3.58 \\
\hline Yield stress at $\varepsilon^{s}=2.0 \%$ & $\sigma_{y}^{s}$ & $\mathrm{MPa}$ & 16.72 & 10.26 & 5.05 \\
\hline Yield stress at $\varepsilon_{y}^{s}=5.0 \%$ & $\sigma_{y}^{s}$ & $\mathrm{MPa}$ & 16.72 & 10.26 & 5.28 \\
\hline Offset distance from mid-surface & $d$ & $\mathrm{~mm}$ & & 5.0 & \\
\hline
\end{tabular}

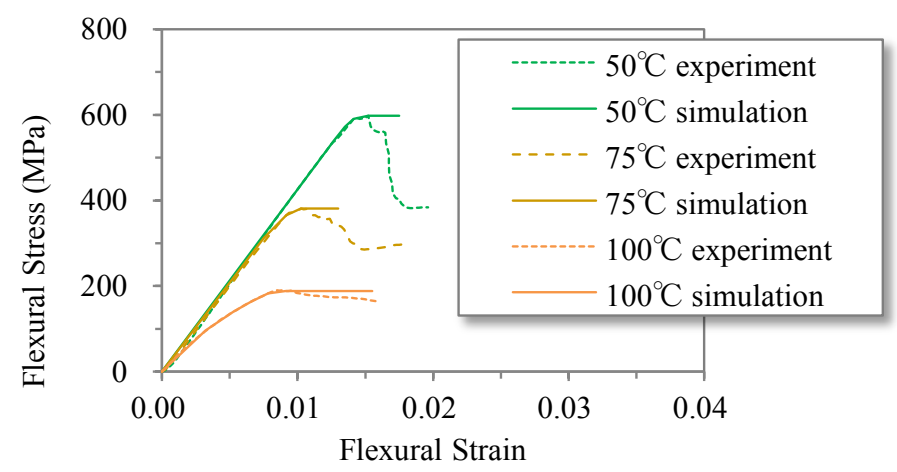

Fig. 4 Comparison of bending responses between simulation and experimental results under 3 point bending tests. We can see good agreements between the simulation and experimental results over $\mathrm{T}_{\mathrm{g}}$.

\section{$3 \cdot 2$ 面内挙動の材料モデル構築}

次に, 提案モデルの各温度に対する面内せん断挙動の表現性を検証するため, +/-45 方向に試験片を伸張させる bias-extension 試験により CFRTP シートのせん断特性を計測した。試験片は長さ $150 \mathrm{~mm}$, 幅 $25 \mathrm{~mm}$ の短冊型であ り, 試験時の温度は $25{ }^{\circ} \mathrm{C}, 50{ }^{\circ} \mathrm{C}, 100{ }^{\circ} \mathrm{C}, 150{ }^{\circ} \mathrm{C}, 180{ }^{\circ} \mathrm{C}$ およ゙ $200{ }^{\circ} \mathrm{C} の 6$ 条件とした. 繊維束間の接触部は 
ピンジョイントですべりがなく繊維束の引張変形が生じないと仮定すれば, bias-extension 試験の荷重と変位の関 係からせん断応力とせん断ひずみの関係を算出できる(Launay, et al., 2008).
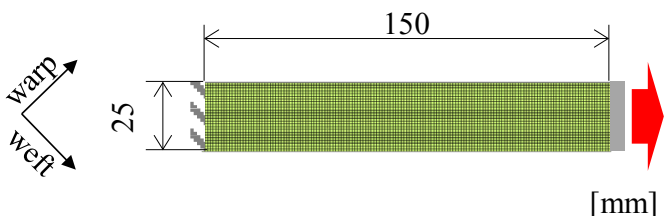

Fig. 5 Dimension of bias-extension test specimen where the warp and weft yarns are oriented initially $+/-45$ to the direction of applied tensile load..

Table 2 Material parameters for textile micromechanical model.

\begin{tabular}{lll|c}
\hline \hline Yarn span & $s$ & $\mathrm{~mm}$ & 2.0 \\
Textile thickness & $t$ & $\mathrm{~mm}$ & 0.24 \\
Yarn width & $w$ & $\mathrm{~mm}$ & 1.7 \\
Yarn cross-sectional area & $S$ & $\mathrm{~mm}^{2}$ & 0.15 \\
Longitudinal Young's modulus & $E^{y}{ }_{11}$ & $\mathrm{MPa}$ & 17357 \\
Transverse Young's modulus & $E^{y}{ }_{22}$ & $\mathrm{MPa}$ & 11.0 \\
Longitudinal shear modulus & $G^{y}{ }_{12}$ & $\mathrm{MPa}$ & 1.0 \\
Shear locking angle & $\theta_{\text {lock }}$ & $\circ$ & 32.0 \\
\hline
\end{tabular}

Table 3 Material parameters for thermoplastic model.

\begin{tabular}{|c|c|c|c|c|c|c|c|}
\hline \multicolumn{3}{|c|}{ Material parameters } & $25^{\circ} \mathrm{C}$ & $50^{\circ} \mathrm{C}$ & $100^{\circ} \mathrm{C}$ & $150^{\circ} \mathrm{C}$ & $180^{\circ} \mathrm{C}$ \\
\hline Young's modulus & $E^{m}$ & $\mathrm{MPa}$ & 3730.02 & 2866.50 & 1105.82 & 18.32 & 4.03 \\
\hline Yield stress at $\varepsilon^{m}{ }_{y}=0 \%$ & $\sigma_{y}^{m}$ & $\mathrm{MPa}$ & 23.15 & 13.46 & 7.52 & 1.90 & 0.23 \\
\hline Yield stress at $\varepsilon^{m}{ }_{y}=0.2 \%$ & $\sigma_{y}^{m}$ & $\mathrm{MPa}$ & 39.02 & 28.41 & 12.09 & 1.96 & 0.23 \\
\hline Yield stress at $\varepsilon^{m}{ }_{y}=0.5 \%$ & $\sigma_{y}^{m}$ & $\mathrm{MPa}$ & 54.49 & 41.22 & 15.97 & 2.04 & 0.23 \\
\hline Yield stress at $\varepsilon_{y}^{m}=2.0 \%$ & $\sigma^{m}{ }_{y}$ & $\mathrm{MPa}$ & 77.16 & 49.55 & 18.33 & 2.16 & 0.23 \\
\hline Yield stress at $\varepsilon^{m}{ }_{y}=5.0 \%$ & $\sigma_{y}^{m}$ & $\mathrm{MPa}$ & 85.10 & 52.24 & 19.72 & 2.23 & 0.23 \\
\hline
\end{tabular}

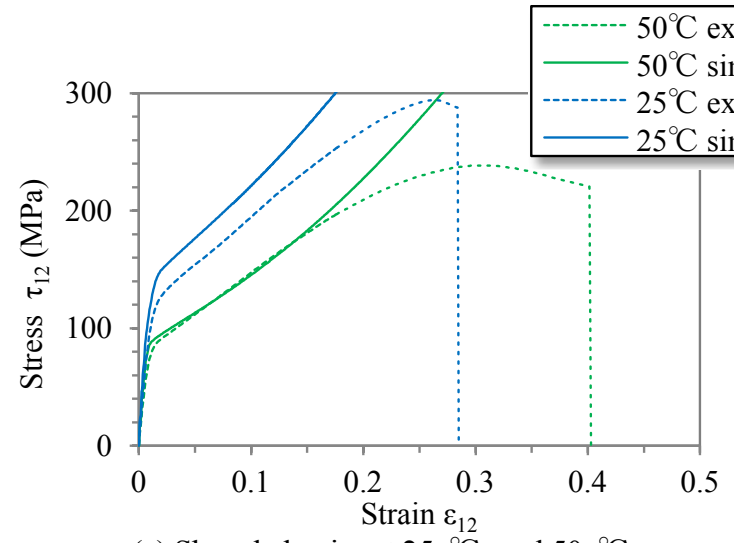

(a) Shear behavior at $25{ }^{\circ} \mathrm{C}$ and $50{ }^{\circ} \mathrm{C}$

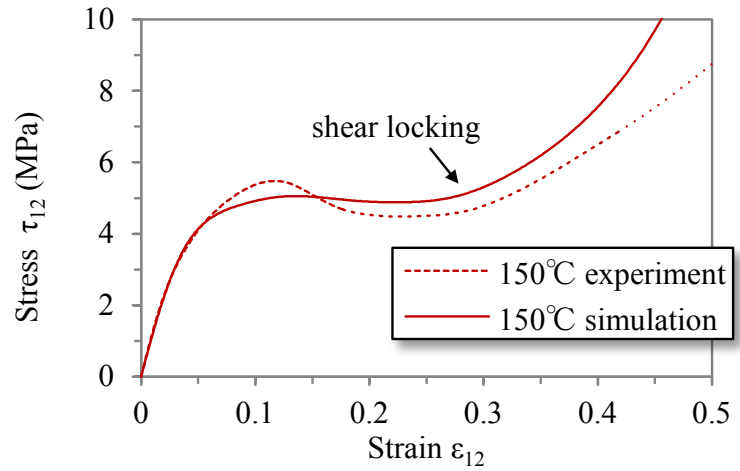

(c) Shear behavior at $150{ }^{\circ} \mathrm{C}$

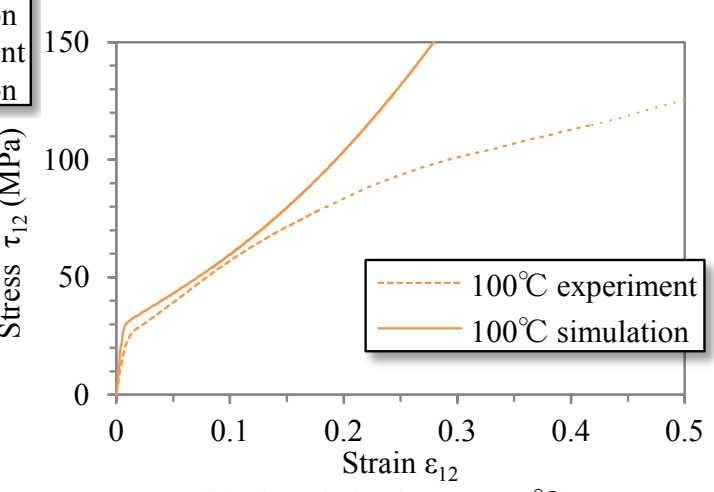

(b) Shear behavior at $100{ }^{\circ} \mathrm{C}$

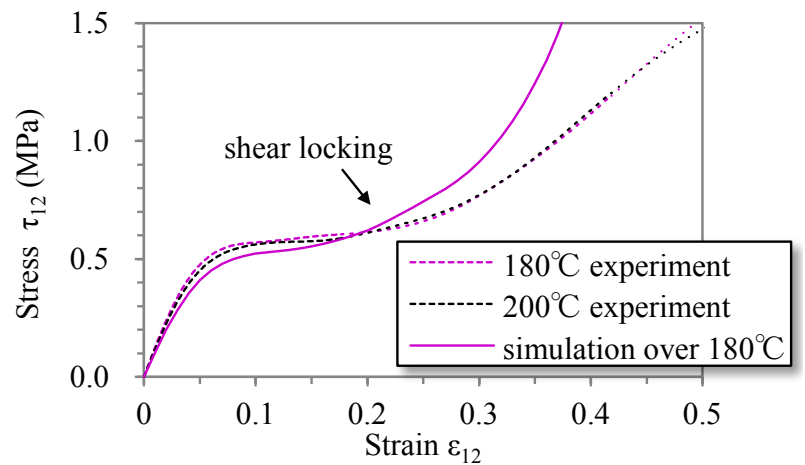

(d) Shear behavior at $180{ }^{\circ} \mathrm{C}$ and $200{ }^{\circ} \mathrm{C}$

Fig. 6 Comparison of shear responses between simulation and experimental results under bias-extension tests. Regarding the temperature range over $T_{g}$, a good correlation with the experimental force up to shear locking angle is obtained. 
提案モデルを用いて，図 5 に示すように bias-extension 試験を有限要素解析寸る. 織物繊維基材モデルに与える 条件を表 2 に, 熱可塑性樹脂モデルに与える物性值を表 3 に示寸. 熱可塑性樹脂モデルに与える PMMA の応力 ひずみ特性について, $\mathrm{T}_{\mathrm{g}}$ 以下の温度 $\left(25{ }^{\circ} \mathrm{C}, 50{ }^{\circ} \mathrm{C}, 100{ }^{\circ} \mathrm{C}\right)$ の特性は CAMPUS データベース(CAMPUS, 2013) を参照した。 $\mathrm{T}_{\mathrm{g}}$ 以下の温度 $\left(150{ }^{\circ} \mathrm{C}, 180{ }^{\circ} \mathrm{C}, 200{ }^{\circ} \mathrm{C}\right)$ ではデータベースがなかったため, 解析結果のせん断ひ ずみとせん断応力の関係が実験結果と一致するように繰り返し計算を行い，各温度の PMMA の応力ひずみ特性 を同定している．なお，試験片は $1 \mathrm{~mm}$ サイズで要素分割し，要素数は 7500 要素である.

図 6 に実験結果と解析結果の荷重変形特性から算出した各温度における面内せん断の応力ひずみ特性を示す.

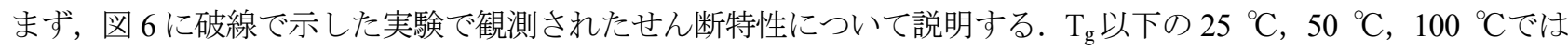
図 6(a)および(b)に示すように弾塑性体のようなせん断特性を示し, 温度に依存して特性が大きく変化しているこ とがわかる。一方， $\mathrm{T}_{\mathrm{g}}$ 以上の $150{ }^{\circ} \mathrm{C} ， 180{ }^{\circ} \mathrm{C} ， 200{ }^{\circ} \mathrm{C}$ では図 6(c)および(d)に示すように，せん断剛性は $\mathrm{T}_{\mathrm{g}}$ 以下

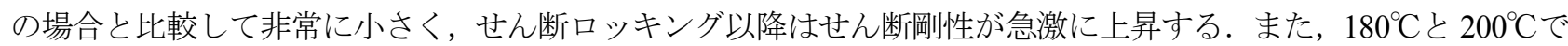
はせん断特性にほとんど差は見られなかった。図 7 に示寸ように， $\mathrm{T}_{\mathrm{g}}$ 以上の温度では，せん断ロッキング以降で は繊維束の間からの樹脂の滲み出しや䋊維束の滑りが生じることが観測された．Harrison ら(Harrison, et al., 2004) の行った高温下における bias-extension試験でもせん断ロッキング以降に繊維束に滑りが生じることが観測されて おり，せん断ロッキング以降において bias-extension 試験で得られたせん断特性が picture frame 試験の結果と比較 して低く見積もられることが指摘されている. そのため, bias-extension 試験で得られたせん断特性はせん断ロッ キングより小さなひずみ領域においてのみ信頼性のあるせん断特性が計測できていると解釈し，解析結果との比 較検証を進める.

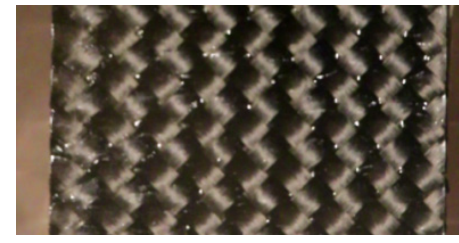

(a) Before deformation

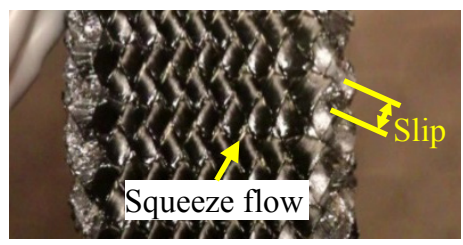

(b) After shear deformation

Fig. 7 Experimental specimens before and after shear deformation at $180{ }^{\circ} \mathrm{C}$. At temperatures higher than $\mathrm{T}_{\mathrm{g}}$, The jagged edge found after the bias-extension test revealed that the test had induced intra-ply slip between yarns as well as trellising after shear locking.

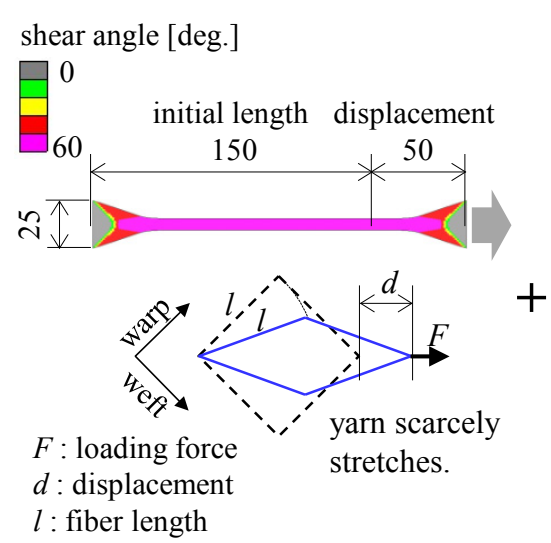

(a) Textile model

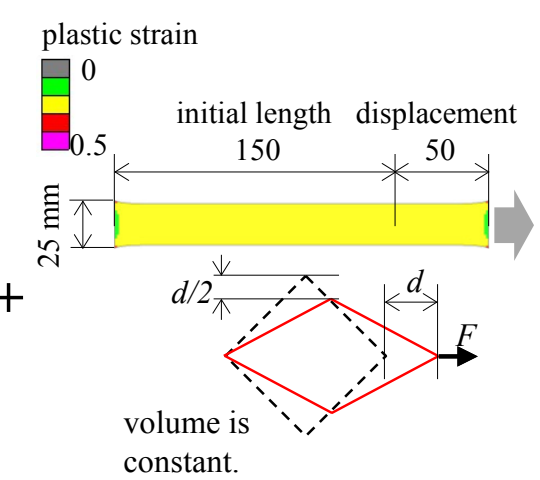

constant

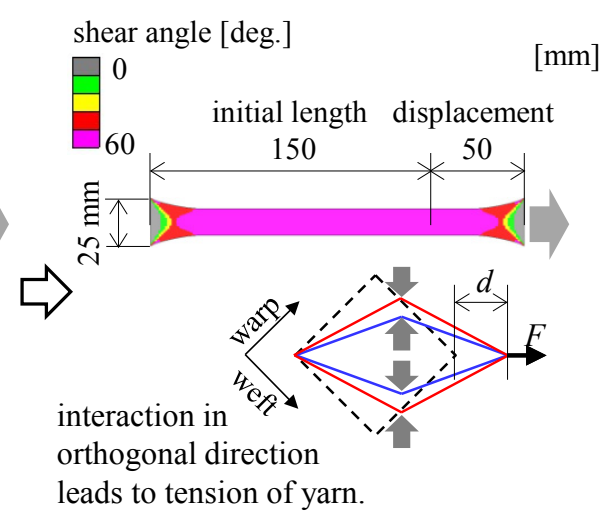

(b) Thermoplastic model

(c) Textile model + Thermoplastic model

Fig. 8 Interaction between textile and thermoplastic model. The textile model tends to shrink under shear deformation, because its yarn scarcely stretches and its dominant deformation is a rotation between yarns at the cross over point. On the other hand, the thermoplastic is calculated under the assumption that the volume remains constant in plastic deformation. Consequently, the conflict of the change in volume prevents the rotation of yarn in the micromechanical textile model.

次に，図 6 に実線で示した各温度における提案モデルのせん断特性の予測精度について記述する． $\mathrm{T}_{\mathrm{g}}$ 以下の温 度域においては，図6(a)および(b)に示すようにせん断ひずみが大きくなると実験結果と乘離が大きくなる.これ 
は, 織物繊維基材モデルと熱可塑性樹脂モデルのポアソン効果による幅方向の変形の違いが原因と考えられる. bias-extension 試験と同様に, 長さ $150 \mathrm{~mm}$, 幅 $25 \mathrm{~mm}$ の短冊型の試験片を用いて, 繊維基材モデルの+/-45 方向, 樹脂モデルおよび本提案 CFRTP モデルの+/-45 方向に $50 \mathrm{~mm}$ の引張変位を与えた際の変形図の比較を図 8 に示寸. 織物繊維基材モデルにおけるせん断変形は, 繊維束の交差部における回転変形が主であり, 繊維束方向にはほと んじ伸び変形は生じない. そのため，+/-45 方向の引張変形下では図 8(a)に示すように面積は縮小され，幅方向に 大きく縮む挙動を示す，一方，熱可塑性樹脂モデルには弾塑性モデルを用いており，塑性変形下では体積一定を 仮定しているため, 図 8(b)に示すように, 繊維機材モデルを伸長させた場合と比べて幅方向の縮み変形は小さい. 両モデルの幅方向の変形の違いにより, 樹脂剛性が大きい $\mathrm{T}$ 以下の温度条件ではせん断ひずみが大きくなる変形 域において繊維基材モデルで䋊維束方向に引張が生じせん断岡性が増加寸る.しかし，プレス成形中に $\mathrm{T}_{\mathrm{g}}$ 以下の 温度で大きなせん断変形が生じると樹脂破断の原因となるため, 適切な条件でプレス成形される場合は, $\mathrm{T}_{\mathrm{g}}$ 以下 の温度で大きなせん断変形を生じることはなく, プレス成形中の変形予測精度に与える影響は少ないと考える.

図 6(c)および(d)に示すように， $\mathrm{T}_{\mathrm{g}}$ 以上の温度では, PMMA 樹脂の応力ひずみ特性を調整することで, せん断口 ッキングに至るまでは解析で実験とよく一致する特性を得ていることがわかる．前述したように，せん断ロッキ ング以降では解析結果のせん断特性が実験より極端に大きくなるが，これは実験にて繊維束すべりが生じている ためであり, bias-extension 試験ではせん断ロッキング以降は正確なせん断特性が計測できないことが原因である.

\section{4. プレス成形解析への適用検証}

提案モデルのプレス成形における変形予測精度を検証するためプレス成形実験を行い，実験と同じ条件を与え るプレス成形解析を行い, 実験結果と解析結果の変形を比較する.

\section{$4 \cdot 1$ プレス成形実験}

まず, プレス成形実験について説明する. 最初, 熱間プレスにて $[(0 / 90)]_{4} お よ ひ ゙[(45 /-45)]_{4}$ の積層 CFRTP シート を作成した. その後, $250 \mathrm{~mm} \times 250 \mathrm{~mm}$ にカットした CFRTP シートをオーブンの中で加熱し, 取り出して金型に セットしプレス成形を行った，常温の金型を用いているため，積層 CFRTP シートは成形過程において金型と接 触する部分より冷却される．プレス成形と同時に CFRTP シートが冷却されるため金型の加熱冷却の熱サイクル が不要であり, 成形サイクル 1 分以内が実現可能な工法である. 金型形状は自動車のサイドフレームを単純化し た S レール形状とし, パンチストロークは $40 \mathrm{~mm}$ でパンチ速度は $20 \mathrm{~mm} / \mathrm{s}$ にてプレス成形した. 成形直前のシー トの温度はサーモグラフィーにより計測し，185 ㄷでほぼ一定な温度分布になることを確認した。

\section{$4 \cdot 2$ 実験と解析の結果比較}

提案モデルを用いて, [(0/90) $]_{4}$ と[(45/-45) $]_{4}$ の積層 CFRTP シートに対し，プレス成形解析を行う．図 9(a)に解析 モデルの概要を, 図 9(b)に金型の断面形状を示す. プレス成形中の温度変化が成形挙動に与える影響を検証する ため, プレス成形中の CFRTP シートの温度低下を考慮せず温度一定として行う解析と, 成形中の温度変化と温 度変化による材料特性の変化を考慮する熱構造連成解析の 2 つの条件で解析を行う. 熱解析では CFRTP シート と金型の接触による熱伝達と CFRTP シートの面内および面外方向の熱伝導による温度変化を計算する．また， 構造解析には陽解法を，熱解析には陰解法を用いる.

表 4 に熱解析に用いる物性值を示す.プレス成形初期のCFRTP シートの温度は $185{ }^{\circ} \mathrm{C} と し$, 金型の温度は $25{ }^{\circ} \mathrm{C}$ とする. CFRTP シートには材料挙動の検証解析で同定した温度毎の材料物性を与える. 各温度間の特性は線形近 似で補間する. なお，金型の線膨張係数は $10^{-5}$ のオーダーであるため, 金型の温度変化による熱膨張が CFRTP シートの変形挙動に与える影響は少ないとして, ダイおよびパンチは表面形状を剛体シェル要素でモデル化する. また, 本研究で実施したプレス成形実験では, 成形中にCFRTP シートの層間にすべりは確認されなかったため, 解析において各層間の寸べりは考慮していない. CFRTP シートと金型間の接触摩擦は, 成形温度域が樹脂の融点 以下の比較的低い温度域であることから本解析ではクーロン摩擦モデルを用い，温度変化は考慮せす摩擦係数は 0.2 で一定として計算する. CFRTP シートの要素サイズは $1 \mathrm{~mm}$ とし, 節点数は, 面内モデルの膜要素と面外モ デルのシェル要素を合わせた要素数は 250000 要素である. 


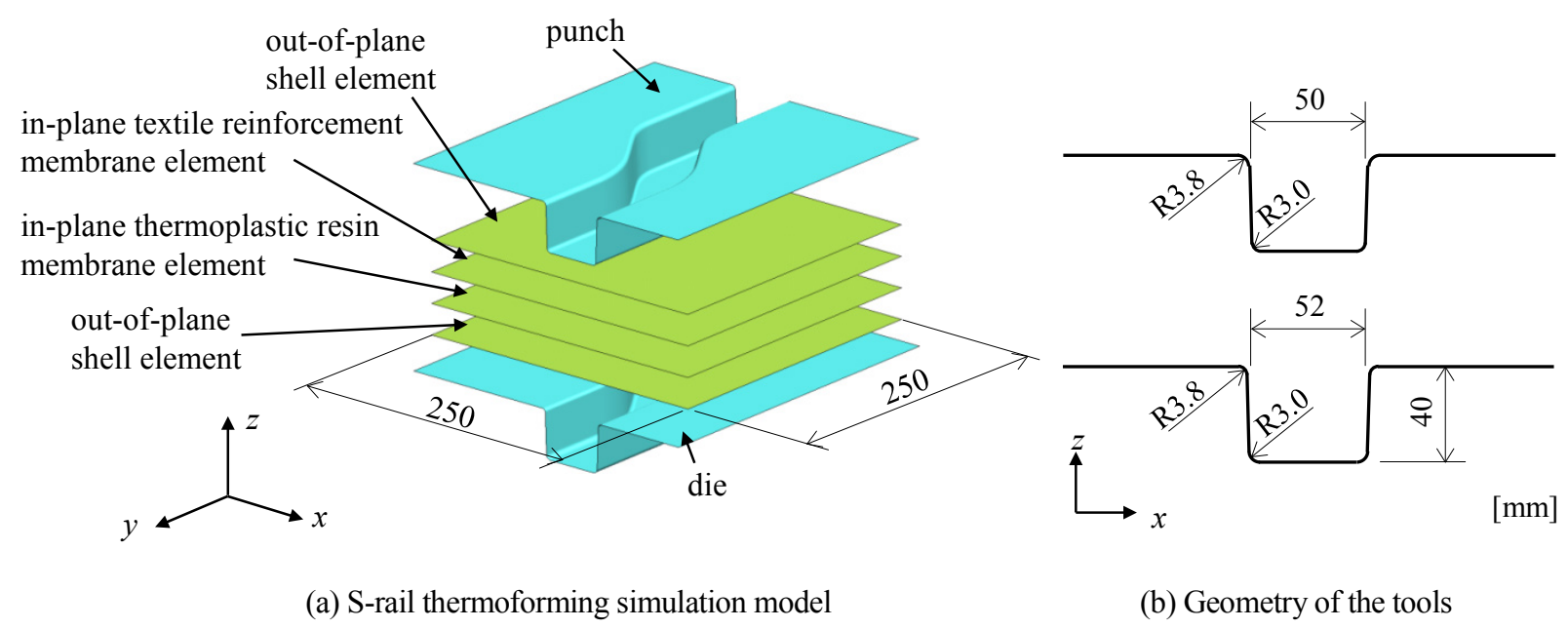

Fig. 9 S-rail simulation model. Pre-consolidated laminates consist of four textile thermoplastic pre-preg layers with simple laminates with $[(0 / 90)]_{4}$ and $[(45 /-45)]_{4}$ lay-ups.

Table 4 Thermal parameters for thermal analysis.

\begin{tabular}{lll|c}
\hline \hline Heat transfer conductance & $h$ & $\mathrm{~mJ} /\left(\mathrm{mm}^{2} \bullet \mathrm{s} \bullet \mathrm{K}\right)$ & 3.0 \\
In-plane thermal conductivity of pre-preg & $K_{l 1}, K_{22}$ & $\mathrm{~mJ} /(\mathrm{mm} \bullet \mathrm{s} \bullet \mathrm{K})$ & 3.4135 \\
Out-of-plane thermal conductivity of pre-preg & $K_{33}$ & $\mathrm{~mJ} /(\mathrm{mm} \bullet \mathrm{s} \bullet \mathrm{K})$ & 0.6825 \\
Heat capacity of pre-preg & $H C$ & $(\mathrm{~mJ} /(\mathrm{g} \bullet \mathrm{K})$ & 1106.0 \\
\hline
\end{tabular}

図 10 に実験，温度一定解析，および温度変化を考慮した熱構造連成解析のプレス成形後の+z方向から見た外 形形状の比較を示す．温度変化を考慮した解析の外形形状は，[(0/90) $]_{4}$ と[(45/-45) $]_{4}$ のいずれの繊維配向でも実験 とよく一致している. 一方, 温度一定解析の結果は, 実験と比較すると部分的に大きく流入しているのがわかる.

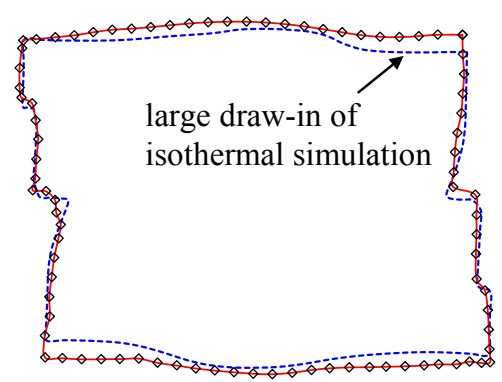

(a) $[(0 / 90)]_{4}$

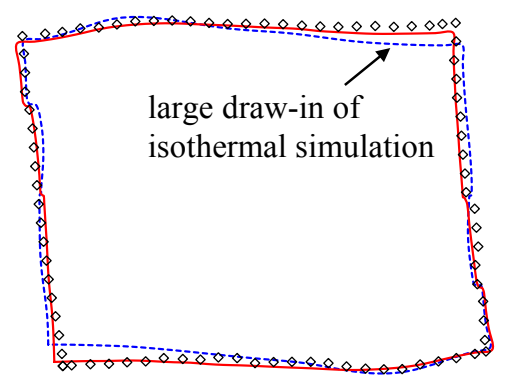

(b) $[(+/-45)]_{4}$ $\checkmark$ experiment

-..-.. isothermal simulation

— non-isothermal simulation

Fig. 10 Comparison of final outlines between experiments, isothermal simulation and non-isothermal simulation of $[(0 / 90)]_{4}$ and $[(45 /-45)]_{4}$ lay-ups. The outlines simulated by the non-isothermal simulations show good agreement with the experimental measurements for both laminates with $[(0 / 90)]_{4}$ and $[(45 /-45)]_{4}$ lay-ups. On the other hand, the outlines simulated by the isothermal simulations are different from the experimental measurements for both lay-ups.

温度一定解析で実験に対して，大きな流入が生じた原因について考察する。困 11 に，[(0/90) $]_{4}$ 積層 CFRTP シ 一トの熱構造連成解析のプレス成形中の CFRTP シートの温度分布を示す. パンチコーナ一付近のたて壁部にお いて，プレス成形中に急激な温度低下が生じているのがわかる．たて壁部では下死点到達前に CFRTP シートの 両面がパンチとダイに接触するため, 成形中に激しい温度低下が生じていると考える. 次に, $[(0 / 90)]_{4}$ 積層 CFRTP シートのプレス成形後のたて壁部のパンチコーナー付近の縦糸と横糸のなす角度について, 図 12 に実験結果と解 析結果の比較を示す，プレス成形実験では，成形後のせん断変形を観測するため，プレス成形前の CFRTP シー トに縦糸と横糸方向に沿って $10 \mathrm{~mm}$ ピッチで直交グリッドを描き，実験を行っている．成形後の縦糸と横糸のな 
す角度は，実験では $71^{\circ}$ ，温度一定解析は $61^{\circ}$ ，熱構造連成解析は $71^{\circ}$ である．図 11 に示したように，熱 構造連成解析ではたて壁部の温度が成形中に急激に低下し，せん断剛性が増加するため，この部分でせん断変形 が抑制されたことがわかる，一方，温度低下によるせん断特性の変化を考慮しない温度一定解析では，大きなせ ん断変形が生じている，温度一定解析では，たて壁部に大きなせん断変形が生じ，実験と比較して一部で大きな 流入が生じたと考える.

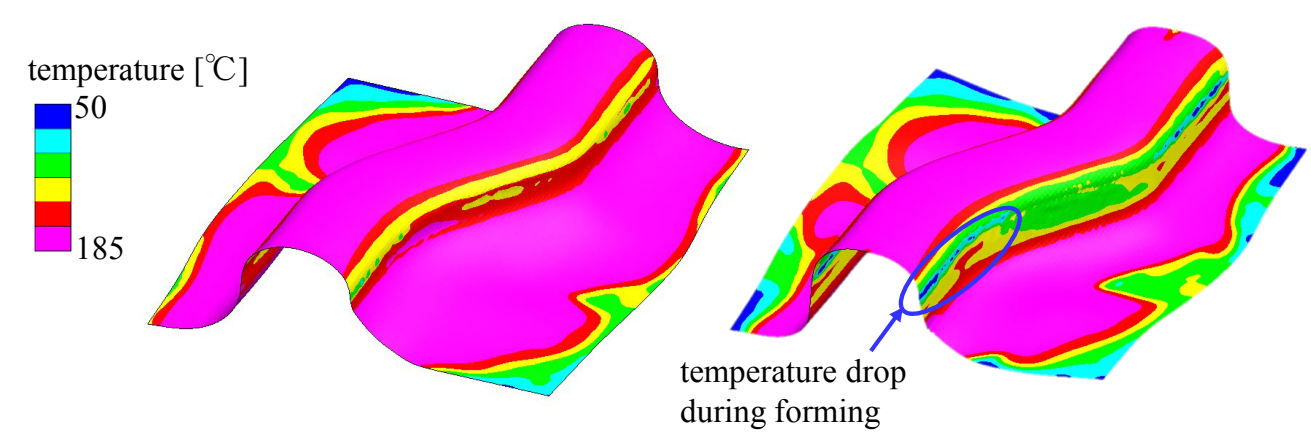

(a) Stroke $20 \mathrm{~mm}$

(b) Stroke $30 \mathrm{~mm}$

Fig. 11 Temperature distribution during non-isothermal forming simulation of $[(0 / 90)]_{4}$ lay-ups. It describes that the temperature of the laminate in the side wall near the corner of punch drops during the forming process. This drop is due to contact with the punch.

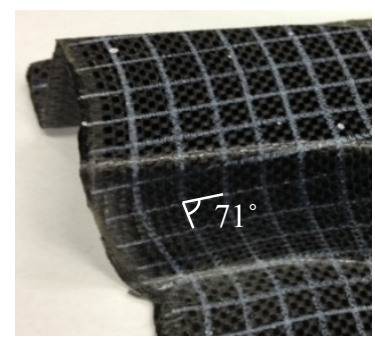

(a) Experiment

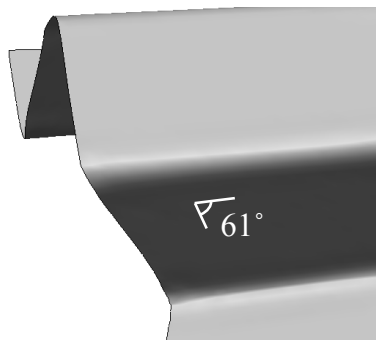

(b) Isothermal forming simulation

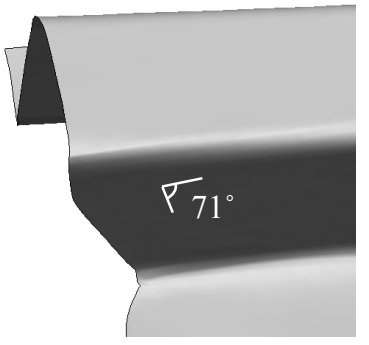

(c) Non-isothermal forming simulation

Fig. 12 Comparison of shear angle of $[(0 / 90)]_{4}$ lay-ups between experiment, isothermal simulation and non-isothermal simulation. Shear deformation in the side wall, especially near the corner of punch is larger than the experiment and the non-isothermal simulation.

常温の金型を用いるプレス成形に対し，提案モデルを用いて熱構造連成解析を行うことにより，成形後の CFRTP シートの外形形状の予測を含め，プレス成形中の変形挙動を予測できることを示せたと考える，なお，本 研究では CFRTP シートのプレス成形解析モデル提案の第一段階として樹脂モデルに等方性の von-Mises 降伏条件 を用いたが，さらに高精度にプレス成形挙動を予測するためには，熱可塑性樹脂の応力ひずみ特性の静水圧依存 性等も考慮した適切な降伏関数の選定が今後の課題と考える.

\section{5. 結 言}

本研究では, 面外の曲げ特性と面内の特性を独立に表現する CFRTP シートのプレス成形解析モデルを提案し た．曲げ特性は，著者らがドライファブリックのプレス成形解析のために提案した膜要素にシェル要素を付加す るモデルを拡張し，CFRTP シートの高温時の非線形性を有する曲げ特性を表現可能とした．また，面内の挙動に は, 繊維基材の特性を表すマイクロメカニカルモデルに, $\mathrm{V}_{\mathrm{f}}$ の変化も考慮できる Ruess モデルを用いて樹脂の応 力成分を付加するモデルを提案した. さらに, 温度により大きく変化する CFRTP シートの面外と面内の特性を 材料実験により把握し, 温度依存性を考慮する CFRTP シートの有限要素モデルを構築した. 構築したモデルを 用いて熱構造連成解析を行い, 常温の金型を用いるプレス成形における CFRTP シートの変形挙動が予測できた. 
CFRTP シートの常温金型を用いたプレス成形は, 成形時間が短く大量生産に適した非常に魅力的な工法である が，プレス成形と冷却を同じ工程で行うため，金型を加熱し CFRTP シートを一定温度に保ってプレス寸る工法 に比べると成形時の制御パラメータが多くなる．本提案モデルを用いたプレス成形解析にて最適な成形条件を模 索することで，CFRTP シートのプレス成形工法のプロセス設計に寄与できるものと考える.

今回のプレス成形実験では成形不良の代表であるしわは生じず，提案モデルによる解析でも同様にしわは確認 されなかった．本モデルはしわの評価に重要な曲げ特性を正確に考慮しているため，しわ発生の予測についても 有効な手法になると考える. 今後，より複雑な金型形状や疑似等方積層などのプレス成形実験との比較により， しわ発生の予測性能についても評価を行う。また，プレス成形中の温度分布の予測精度について実験との比較検 証を行い，熱解析のモデル化手法についても梁く考察する予定である.

\section{謝 辞}

本研究で参考にした実験は平成 24 年度戦略的基盤技術高度化支援事業「熱可塑性 CFRP による車載用大型複雑 形状製品の成形技術の開発」において実施されたものである. 実験データの提供に協力を頂いた株式会社浅野の 中村仁氏，並びに群馬工業高等専門学校専攻科阿部徳秀氏に深く感謝の意を申し上げる.

\section{文献}

Aimene, Y., Hagege, B., Sidoroff, F., Vidal-Salle, E., Boisse, P. and Dridi, S., Hyperelastic approach for composite reinforcement forming simulations, International Journal of Material Forming, Vol.1, No.1 (2011), pp.811-814.

Boisse, P., Zouari, B. and Daniel, J.L., Importance of in-plane shear rigidity in finite element analyses of woven fabric composite preforming, Composites Part A: Applied Science and Manufacturing, Vol.37, No.12 (2006), pp.2201-2212.

CAMPUS ${ }^{\circledR}$ - a material information system for the plastics industry, Download Desktop Version (online), available from $<\mathrm{http}: / /$ www.campusplastics.com/campus $>$, (参照日 2013 年 12 月 12 日).

Haanappel, S.P., ten Thije, R.H.W., Sachsa, U., Rietman, B. and Akkerman, R., Formability analyses of uni-directional and textile reinforced thermoplastics, Composites Part A: Applied Science and Manufacturing, Vol.56 (2014), pp.80-92.

Hallquist, J.O., LS-DYNA Theory Manual (2006), ISBN 0-9778540-0-0.

Harrison, P., Clifford, M.J. and Long, A.C., Shear characterisation of viscous woven textile composites: a comparison between picture frame and bias extension experiments, Composites Science and Technology, Vol.64, No.10-11 (2004), pp.1453-1465.

Hull, D. and Clyne, T.W., An Introduction to Composite Materials (1996), pp.60-77, Cambridge University Press.

Ivanov, I. and Tabiei, A., Loosely woven fabric model with viscoelastic crimped fibres for ballistic impact simulations, International Journal for Numerical Methods in Engineering, Vol.61,No.10 (2004), pp.1565-1583.

Launay, J., Hivet, G., Duong, A.V. and Boisse, P., Experimental analysis of the influence of tensions on in plane shear behavior of woven composite reinforcements, Composites Science and Technology, Vol.68, No.2 (2008), pp.506-515.

Long, A.C., Composite forming technologies (2007), pp.256-276, CRC Press.

Margossian, A., Ding, M., Avila Gray, L., Bel, S. and Hinterhölzl, R., Flexural characterisation of unidirectional thermoplastic tapes using a dynamic mechanical analysis system, Proceedings of the 16th European Conference on Composite Materials (ECCM16) (2014), 0453.pdf.

西正人, 平島禎, 倉敷哲生, せん断挙動の引張依存性を考慮したドライファブリックのプレス成形解析，日本材料 学会会誌, Vol.63, No.5 (2014a), pp.380-385.

西正人, 平島禎, 倉敷哲生, 有限要素法による単層ドライファブリックの成形シミュレーション, Journal of Textile Engineering, Vol.60, No.3 (2014b), pp.51-59.

Sharma, S.B. and Sutcliffe, M.P.F., A simplified finite element model for draping of woven material, Composites Part A: Applied Science and Manufacturing, Vol.35, No.6 (2004), pp.637-643.

Skordos, A.A., Aceves, C.M. and Sutcliffe, M.P.F., A simplified rate dependent model of forming and wrinkling of pre-impregnated woven composites, Composites Part A: Applied Science and Manufacturing, Vol.38, No.5 (2007), pp.1318-1330.

Wang, P., Hamila, N. and Boisse, P., Thermoforming simulation of multilayer composites with continuous fibres and thermoplastic matrix, Composites Part B: Engineering, Vol.52 (2013), pp.127-136. 


\section{References}

Aimene, Y., Hagege, B., Sidoroff, F., Vidal-Salle, E., Boisse, P. and Dridi, S., Hyperelastic approach for composite reinforcement forming simulations, International Journal of Material Forming, Vol.1, No.1 (2011), pp.811-814.

Boisse, P., Zouari, B. and Daniel, J.L., Importance of in-plane shear rigidity in finite element analyses of woven fabric composite preforming, Composites Part A: Applied Science and Manufacturing, Vol.37, No.12 (2006), pp.2201-2212.

CAMPUS ${ }^{\circledR}$ - a material information system for the plastics industry, Download Desktop Version (online), available from $<$ http://www.campusplastics.com/campus >, (accessed on 12 December, 2013).

Haanappel, S.P., ten Thije, R.H.W., Sachsa, U., Rietman, B. and Akkerman, R., Formability analyses of uni-directional and textile reinforced thermoplastics, Composites Part A: Applied Science and Manufacturing, Vol.56 (2014), pp.80-92.

Hallquist, J.O., LS-DYNA Theory Manual (2006), ISBN 0-9778540-0-0.

Harrison, P., Clifford, M.J. and Long, A.C., Shear characterisation of viscous woven textile composites: a comparison between picture frame and bias extension experiments, Composites Science and Technology, Vol.64, No.10-11 (2004), pp.1453-1465.

Hull, D. and Clyne, T.W., An Introduction to Composite Materials (1996), pp.60-77, Cambridge University Press.

Ivanov, I. and Tabiei, A., Loosely woven fabric model with viscoelastic crimped fibres for ballistic impact simulations, International Journal for Numerical Methods in Engineering, Vol.61,No.10 (2004), pp.1565-1583.

Launay, J., Hivet, G., Duong, A.V. and Boisse, P., Experimental analysis of the influence of tensions on in plane shear behavior of woven composite reinforcements, Composites Science and Technology, Vol.68, No.2 (2008), pp.506-515.

Long, A.C., Composite forming technologies (2007), pp.256-276, CRC Press.

Margossian, A., Ding, M., Avila Gray, L., Bel, S. and Hinterhölzl, R., Flexural characterisation of unidirectional thermoplastic tapes using a dynamic mechanical analysis system, Proceedings of the 16th European Conference on Composite Materials (ECCM16) (2014), 0453.pdf.

Nishi, M., Hirashima, T. and Kurashiki, T., Dry fabric forming analysis considering the influence of tensions on in-plane shear behavior, Journal of the Society of Material Science, Japan, Vol.63, No.5 (2014a), pp.380-385 (in Japanese).

Nishi, M., Hirashima, T. and Kurashiki, T., Single layered dry fabric forming simulation by finite element analysis, Journal of Textile Engineering, Vol.60, No.3 (2014b), pp.51-59 (in Japanese)

Sharma, S.B. and Sutcliffe, M.P.F., A simplified finite element model for draping of woven material, Composites Part A: Applied Science and Manufacturing, Vol.35, No.6 (2004), pp.637-643.

Skordos, A.A., Aceves, C.M. and Sutcliffe, M.P.F., A simplified rate dependent model of forming and wrinkling of pre-impregnated woven composites, Composites Part A: Applied Science and Manufacturing, Vol.38, No.5 (2007), pp.1318-1330.

Wang, P., Hamila, N. and Boisse, P., Thermoforming simulation of multilayer composites with continuous fibres and thermoplastic matrix, Composites Part B: Engineering, Vol.52 (2013), pp.127-136. 